\title{
"LA ALEGRE LIBERTAD EN LA CATÁSTROFE": TENSIONES ENTRE LENGUAJE Y VERDAD EN LA POESÍA ESPAÑOLA JOVEN (2011-2018)
}

"La alegre libertad en la catástrofe": Tensions between language and truth in Spanish young poets (2011-2018)

\author{
ÁLVARO LÓPEZ FERNÁNDEZ \\ UNIVERSIDAD COMPLUTENSE DE MADRID (ESPAÑA) alfernandez@ucm.es
}

RECIBIDO: 10 DE ABRIL DE 2018 ACEPTADO: 28 DE JUNIO DE 2018

RESUMEN: En los últimos años se han publicado en España numerosos poemarios de corte vanguardista, escritos por autores jóvenes, que se caracterizan por su experimentación con el lenguaje. A pesar de ello, la cobertura crítica que han recibido ha sido bastante esporádica, especialmente desde una perspectiva comparada. En compensación, el presente artículo pretende estudiar las afinidades estéticas en torno a la relación entre "lenguaje" y "verdad" que manifiestan varios de ellos. El tratamiento de este tema actualiza, al cabo, debates tan influyentes como la poesía en tanto conocimiento o comunicación que marcaron el devenir literario del pasado siglo, y los adapta a un nuevo registro metatextual. Para este propósito se han seleccionado y analizado textos de Cristian Piné, Ángela Segovia, Unai Velasco, Berta García Faet, Arantxa Romero, Gema Palacios, Álvaro Guijarro, Bibiana Collado, Lucía Boscá o Lola Nieto. Autores todos menores de 35 años, nuevos novísimos para el siglo XXI, vinculados entre sí (pues no se adhieren a ningún grupo o etiqueta colectivos) por su conciencia lingüística y voluntad renovadora.

PALABRAS CLAVE: poesía española joven, verdad, lenguaje, experimentación, siglo XXI

ABSTRACT: In the last years, many books of poems on an avant-garde line have been published, characterised by language experimentation and written by young authors. However, the attention of the critics, especially from a comparative perspective, has been just occasional. Therefore, the current paper aims to study the aesthetic affinities around the relationship between "language" and "truth" that is shown in these books of poems. Ultimately, the paper's approach updates the influential discussion about poetry as knowledge or as communication, which set the literary scene of the last century, and adapts it to a new metatextual register. To achieve this goal, texts by Cristian Piné, Ángela Segovia, Unai Velasco, Berta García Faet, Arantxa Romero, Gema Palacios, Álvaro Guijarro, Bibiana Collado, Lucía Boscá or Lola Nieto have been selected and analysed. They are all younger than 35 years old, new novísimos for the 21 st century, linked by their linguistic consciousness and reformation willingness, since they do not adhere to any group nor label.

KEYWORDS: Spanish young poets, truth, language, experimentation, 21st century

López Fernández, Álvaro

“'La alegre libertad en la catástrofe’: Tensiones entre lenguaje y verdad en la poesía joven (2011-2018)”

Kamchatka. Revista de análisis cultural 11 (Julio 2018): 179-203

DOI: 10.7203/KAM.11.12286 ISSN: 2340-1869

Monográfico LECTURAS DEL DESIERTO: NUEVAS PROPUESTAS POÉTICAS EN ESPAÑa 
A partir de un entramado de textos de diferentes autores jóvenes -todos menores de 35 años- este artículo quiere ofrecer una muestra de qué está ocurriendo en la poesía española actual menos accesible o más audaz formalmente, sobre todo cuando esta se orienta a su propia validación expresiva. En este sentido, las páginas que siguen registrarán las direcciones de una escritura metapoética en la que la significación de las palabras y del poema mismo se deshace o se rehace en su búsqueda del lenguaje (y de la verdad). Ante tal horizonte puede extrañar la ausencia de una contextualización previa que sobrevuele las líneas principales de los autores más inclinados a la experimentación de la generación inmediatamente anterior, la de los nacidos en los 70. La influencia, sin embargo, que sus trabajos han ejercido en los poetas sucesivos ha sido salvo excepciones como Cuánto dura cuanto (2007, reeditado en 2010), de María Eloy-Garcíabastante ocasional y quebradiza, entre otras cosas porque buena parte de sus hitos vanguardistas (Desfrío [2015], de Esther Ramón, Caoscopia [2012], de Yaiza Martínez, Desdecir [2013], de Enrique Cabezón, Mòb [2013], de Minke Wang, Tratado de entrañeza [2014], de Mario Martín Gijón, etc.) se publican significativamente en la misma horquilla cronológica que las obras más rupturistas (y precursoras) firmadas por los autores nacidos ya en los años 80 y principios de los 90 , por lo que en todo caso habría que dar cuenta de una correspondencia mutua y horizontal. Uno de los rasgos distintivos, no obstante, de estos poetas más jóvenes parece ser su renovada insistencia en plasmar la tensión que media entre los dos elementos referidos. De ahí que, para explicar mejor sus variaciones, convenga saltarse varias décadas de producción poética, donde el modelo experiencial ha sido el predominante, y volver por un momento a la antología novísima de José María Castellet, habitualmente entendida como el umbral de la posmodernidad poética en España.

\section{LA SANCIÓN DE LA VERDAD. INTRODUCCIÓN}

Basta releer la dedicatoria de Castellet en su antología Nueve novísimos poetas españoles (1970) para apreciar que está imitando, desde la distancia, el estilo de los autores que prologa. Solo así puede entenderse que los recuerdos musicales de Aretha Franklin, Julie Driscoll o Mae West se unan en la pasarela de agradecimientos a los antologados Ana María Moix o Pere Gimferrer, que tanto participó en el montaje del volumen. Castellet, no en vano, pretendía hacer de su prólogo un artefacto filológico y publicitario que sirviera como espejo formal, pero también provocador, de sus novísimos. Para ello saturó el texto de extractos de sus escritores fetiche, preferiblemente alejados de la tradición hispánica (Fitzgerald, Henry James...), insistió con polémica en su visión de un comunismo esteticista -de póster-, se recreó en su bagaje culturalista privilegiado, lleno de referencias exóticas..., y no escatimó las citas a sus supuestos teóricos de cabecera, como Susan Sontag y, sobre todo, Roland Barthes. Al fin y al cabo, para Castellet nos encontrábamos en una época mítica y mitificadora que, desde Marilyn Monroe a Ernesto Che Guevara, producía iconos 
populares en serie, capaces de llegar hasta los más recientes poemas españoles. De ahí que anticipándose a la extrañeza que podía causar esto en sus lectores- se acogiera en su prólogo a aquella tesis de Barthes según la cual "el mito se ha convertido hoy en un habla (parole), es decir, en un mensaje. No es un concepto, un objeto o una idea: es un modo de significación, una forma". A resultas de lo cual -infería Castellet- el mito "se muestra ahistórico y apolítico y adquiere un valor absoluto", pues se trata, por definición, "de un valor que no exige la sanción de la verdad" (1970: 27-28).

Medio siglo de historia literaria después, resulta significativo que Castellet dedicara tanto esfuerzo en aclarar (o blanquear) esta significación pura del mito y, sin embargo, no analizara en ningún momento su inserción y construcción lingüísticas (el otro gran puntal de Mythologies [1957] de Barthes) en los textos de sus autores más vanguardistas. ¿Acaso no fue la progresiva adaptación clásica de su entramado lingüístico $-\mathrm{y}$ no la significación de sus temas- una de las claves de la deriva postnovísima años más tarde? Esta ausencia analítica cobra más importancia si admitimos que Castellet hizo de su prólogo un afortunado simulacro de las señas más superficiales de la estética que él mismo estaba patentando..., mientras que algunos poetas incluidos en su promoción, como Guillermo Carnero, tan solo veían "una única característica común [entre los novísimos]: restaurar la primacía del lenguaje" (en Batlló, 1974: 303). Empeño liminar este que hoy vuelven a suscribir, a través de sus obras, todos los autores sobre los que versa este artículo, sin atender a mayores intentos de agrupación entre ellos. Se cristalizan así avisos recientes, como los del poeta Eduardo Moga, sobre la llegada de una nueva vanguardia poética, de corte experimental, "que persigue la subversión léxica y sintáctica” (Moga, 2015: 66).

Curiosamente, dos años antes de la irrupción de Nueve novísimos, José Batlló había publicado un volumen menos conocido, Antología de la nueva poesía española (1968), donde textos de jóvenes poetas cercanos a la futura aura novísima, como Vázquez Montalbán, Ullán y Gimferrer, aparecían ya junto a buena parte de los prebostes de la generación de los 50 (Caballero Bonald, Gil de Biedma, Valente...). Lo interesante (y lúcido, si atendemos a la lista de autores incluidos) de la selección de Batlló residía en su motivación: reunir a aquellos poetas "que hayan aportado una mayor renovación, o sean capaces de aportarla a nuestra poesía” (en Lanz, 1993: 580). Renovación entendida, a la luz de sus decisiones, en una clave lingüístico-formal. Vista la atención crítica -necesaria desde un plano semiótico- que están recibiendo las tendencias más comerciales de la poesía española actual, resulta tentador, en contraste, rescatar y adaptar por un momento la metodología de Batlló, aunque sea por un afán especulativo, y preguntarse: ¿quiénes conformarían hoy esta nómina de (potenciales) autores renovadores?

Hablamos -situémonos- de autores herederos de la "maraña poética", en palabras de Prieto de Paula (2010: 28), que se había originado entre los años noventa y los dos mil, después de la disolución de la poesía de la experiencia como corriente aglutinante mayoritaria. Una disolución que no supuso, sin embargo, que el modelo experiencialista se estancara ni impidió que desarrollara variantes expresivas en el siglo XXI, lo que ha terminado por acercar a la estética, por agotamiento, a unas cotas de "pesadilla" (actualizando la etiqueta de Castellet) ${ }^{1}$ para

\footnotetext{
${ }^{1}$ Castellet se sirvió de esta fórmula, "pesadilla estética", que Antonio Machado acuñó en su discurso de ingreso en la Real Academia, para definir la sensación de saturación que la poesía social había acabado causando en los nuevos autores (1970: 15).
} 
la mayoría de las voces rupturistas del período. Este panorama se agrava si tenemos en cuenta que, diez años después, la academia seguía sin desbrozar aquella "maraña poética" que había observado Prieto de Paula, especialmente en las ramas que más se alejaban de la norma confesional. De hecho, en el año 2010, la profesora María Ángeles Naval todavía atribuía al conjunto de la poesía española última una indefinida "exuberancia selvática" (fruto de excesivas panorámicas, premios y antologías), que parecía "impaciente por el advenimiento del canon, de algún canon" (Naval, 2010: 119).

No es la intención de este trabajo proponer o justificar una lista prescriptiva de autores jóvenes que estén renovando el campo poético español; pero sí busca adentrarse en algunos de sus poemarios más atrevidos en el plano formal, con el fin de alumbrar la relación expresa que están desarrollando entre "lenguaje" y "verdad". No en vano, si seguimos una lógica de continuidad, esta relación supone una nueva onda o proyección de las grandes preocupaciones que han marcado la lírica española del siglo XX, al menos desde la generación del 50 y su debate en torno a la poesía como conocimiento o comunicación (categorías diferenciadas, sin ir más lejos, por la acepción y foco de la verdad que se quiere consignar). Aun así, a diferencia del estudio de ondas más representativas, como la construcción de la identidad del sujeto contemporáneo (Bagué Quílez y Santamaría, 2013; Mora, 2016) o el papel del compromiso en la poesía joven actual (Bagué Quílez, 2015; García, 2018), aún no ha habido ningún acercamiento investigador a este vínculo tan reciente como revelador entre lenguaje y verdad, planteado en términos de tensión. Una tensión conflictiva.

La precisión se antoja necesaria para distinguir esta tensión de una tensión inherente entre objetos, como la que expuso Slavoj Zizek en su libro Visión de paralaje (2006), basado en el concepto astrofísico que recoge la variación de la posición de un astro al cambiar la posición del observador. Así las cosas, este trabajo no se detendrá apenas en apreciar la discordancia entre aquello que el poeta se propone expresar y lo que realmente expresa (aunque pueda mostrar su desconfianza en tal labor), ni tampoco en recomponer los distintos ángulos de su discurso, a la manera orteguiana (como sucedía en el poemario reticular Matar a Platón [2004], de Chantal Maillard). Antes de eso, el análisis se concentra en un fenómeno muy concreto -y repetido-: la materialización explícita de la verdad como entidad (de deseo, de realidad, etc.) que provoca una confrontación lingüística dentro del mismo poema.

Una de las vías más intuitivas para desarrollar o resolver esta confrontación es que la palabra o la verdad terminen encarnándose y adquieran visos míticos. Lo sugerente de este planteamiento es que por definición ninguna de las dos categorías -valga la paradoja con la visión de Barthes/Castellet- puede escapar entonces de la propia sanción del Lenguaje (el suyo) y de la Verdad (la suya) que les incluye respectivamente y de la que son valores absolutos, pero ahora también representativos. Se percibe en este punto la influencia de la apropiación formal de los autos sacramentales y otros textos litúrgicos que se llevó a cabo durante las vanguardias, así como la pervivencia de una dialéctica estético-existencialista que ha adquirido nuevas connotaciones en el siglo XXI.

En cualquier caso, pese a la sucesiva abundancia y variedad de sus propuestas, no se puede interpretar a estas alturas críticas la poesía española del siglo XXI como un todo (maraña, selva o 
mar) uniforme en su progresión. Se han producido puntos de inflexión en su desarrollo. Uno de los más evidentes para la apertura del escenario lírico a una nueva juventud creadora (y que indica la fecha de inicio de este corpus) fue el año 2011. Después de todo, a nivel institucional se convoca por primera vez en 2011 el Premio Nacional de Poesía Joven "Miguel Hernández"; a nivel editorial se publica la antología de cuño generacional (referencia ineludible para todas las posteriores) Tenían veinte años y estaban locos, de Luna Miguel; y, en lo que respecta a los intereses de este trabajo, aparece la auto-selección de poemas de Raquel Lanseros, Fernando Valverde y Daniel Rodríguez Moya, Poesía ante la incertidumbre, en cuyo prólogo-manifiesto "expresan a las claras su disconformidad con la tendencia tan experimental como oscura" (en Iravedra, 2016: 164) que reconocían ya como la orientación más creciente de la nueva poesía. Una dirección viciada por su "artificio estérill" y su "irracionalismo como dogma", los mismos cargos que, elocuentemente, se imputaron en su día a los poetas novísimos...

En efecto, ese supuesto estilo "oscuro" -que nos ocupa-, de lectura más exigente, no ha dejado de consolidarse desde entonces, sustentado en plataformas como la revista de creación Kokoro, cuyo primer monográfico aparecerá meses después, en junio de 2012. Desde entonces el sello ha publicado 18 números e impulsado el recopilatorio Voz vértebra. Antología de poesía futura (VVAA: 2017), donde los autores adoptan (im)posibles identidades heterónimas de los próximos milenios. A pesar de ello, la mayoría de las últimas compilaciones sobre poesía actual (véanse Floriano y Rivero Machina, 2016 y Morante, 2016) no solo delatan una cierta propensión a las vertientes más cercanas a la experiencia, sino que han acentuado el aislamiento formal entre sus integrantes (que ya apuntaba Tenían veinte años y estaban locos). De acuerdo con sus introducciones podría parecer, incluso, que hay tantas tendencias como personas antologadas, lo que ha reforzado la impresión de vivir en un horizonte de "poetas-isla" (Sánchez, 2015: 6). Ante esta perspectiva, confío en que el análisis que sigue pueda esclarecer algunas claves del zeitgeist estético de la poesía española de voluntad más renovadora; o al menos demostrar que existen una serie de concomitancias en torno a un mismo tema, que se puede saltar de una isla a otra como partes de un mapa común.

\section{LAS ISLAS DESPEJADAS. NUDO}

Por seguir con la metáfora, si hubiera que tomar la obra de algún poeta de ese archipiélago como guía en la relación entre lenguaje y verdad, convendría examinar los tres libros de Cristian Piné [1991] publicados hasta la fecha, especialmente el segundo, Al envés de la voz (2014).

Haciendo honor a su título este poemario se abre simbólicamente con una sección (la primera de siete) de siete poemas en orden descendente titulada "Voz". Una voz genérica que no remite a ningún principio (o verbo), pero que consigna una ley cosmológica -que se realiza en el propio texto- nada más comenzar: "la palabra continúa en movimiento/ aunque quede desmembrada" (Piné, 2014: 8). Ante esta marcha imparable hasta su fragmentación la labor del escritor se equiparará con la de "un paciente sexador de escarabajos", al que se le conmina, a través de un drástico cambio de foco a la segunda persona en el siguiente versículo: "debes caminar alrededor de los profetas". 
La advertencia toma cuerpo en el próximo poema ("Voz: VI"), donde Piné plasma con reminiscencias bíblicas una especie de arte de buen decir/crear a través de la palabra -véase en este punto la mención de los "insectos" en el primer verso, que remiten a los escarabajos de la composición anterior-, para Emeth, "el más fiel” heredero de un padre (dios, rey, sabio...) que refleja con grandiosidad la creencia primitiva de poseer a los objetos a través del conocimiento y enunciación de su nombre. La palabra como misterio y materia rectora del universo (que cabe en una de ellas). Sucede, sin embargo, que la interpretación de este texto de Cristian Piné tiene un doble fondo, consecuente con su propio contenido, es decir, con el nombre de quien invoca para ser instruido en el lenguaje, "Emeth".

Emeth, uno de los términos más repetidos en el Antiguo Testamento, significa Verdad en hebreo o, más concretamente, fidelidad a la Verdad [Cantos Aparicio, 2014: 644]. El matiz no es nada superficial. Nótese que según la acepción que otorguemos a "Emeth" tanto su padre como él podrían representar esa Verdad -que su nombre está diciendo- en el poema, pues era la fidelidad lo que convertía a este en merecedor de sus consejos. A su vez, era la (fidelidad a la) verdad, entendida como adecuación lingüística con la realidad, el objetivo que intentaba transmitir la vOz poética. Una vOz que ahora, en un paralelismo alegórico con Emeth, se ha convertido en La voz de la poesía, que se dirige a la Verdad o emana de ella. Tal es su fuerza que, en su completo desarrollo, solo podría ser apelada por agentes telúricos tan poderosos como un volcán, de sonido "leve" a su lado. Copio el texto completo para que puedan apreciarse ambos niveles metaliterarios de lectura:

Emeth, es tan difícil observar al insecto perderse en el barro y decir que está perdido, tan difícil escuchar cómo nace una tormenta y decir que está naciendo, es muy difícil palpar tu mano densa y decir que aún estás vivo.

Déjame enseñarte, Emeth, cómo nombrar la sangre de los ojos. cómo apoderase de la identidad del rayo hasta que la leve voz del volcán pueda nombrarte.

Emeth, eres el más fiel de mis hijos y por eso quiero besar la mano densa con la que reduces el mundo a su corteza. Déjame enseñarte cómo las ideas se muestran torpes en la danza del destino.

En medio de ese baile estrafalario se desploman y es tan difícil decir en voz alta que debajo de la tierra está el silencio (Piné, 2014: 9).

Si tomamos cierta distancia, se advierten en esta escena cosmogónica algunas claves del pensamiento de Martin Heidegger -por ejemplo de su conferencia "El origen de la obra de arte" (1935) -, una de las auctoritas que más influyó en el debate de medio siglo sobre la poesía en tanto comunicación o conocimiento, como ha estudiado, entre otros, el profesor Juan José Lanz (2009). Heidegger, igual que la voz de Emeth, concebía el lenguaje como "un acto de nombrar esencial y primordial, en el que el poeta revela el ser de lo ente en su existencia" (en Lanz, 2009: 
28). Por ello, el lenguaje no funcionaba "ante todo como un medio de comunicación", sino también de indagación e incluso como un medio de "apertura" en el vacío (o en el silencio, por hilvanar la teoría con el último verso de Piné). En esta coyuntura, la esencia de la poesía -que por su trabajo lingüístico es, a su vez, la esencia del arte- consistía entonces, según el pensador alemán, en "la fundación de la verdad" (Heidegger, 1996: 54), presentada en su propio acontecer existencial. En lo que respecta al acontecer, tan geométrico, de Al envés de la vor, se acabará cumpliendo su vaticinio inicial sobre "la palabra", que quedará irremediablemente fraccionada en sílabas como unidad mínima de significación (o trascendencia): "la sílaba en alabanza para existirte/ y hacer que la piedra arda" (Piné, 2014: 34), "la sílaba es la vez última en la que alcanza/ la oración a los blasfemos y a la falsa cicatriz" (Piné, 2014: 60)...

El texto sobre Emeth tiene, no obstante, un interés adicional fuera de Al envés de la voz: las similitudes estéticas que guarda con una composición del libro Plétora (2017), de Arantxa Romero [1990].

En este recientísimo poemario el sentido de la verdad -sobre el que orbitan también no pocos versos- se encuentra percutido por dos citas, en cursiva, que Arantxa Romero reformula a partir de otras precedentes. En la primera cita, "en el principio estaba la repetición" (2017: 8), la autora sustituye "el verbo" del "Evangelio de Juan" por una noción de circularidad ritual, en diálogo con la poética de variaciones de Chantal Maillard ("toda verdad repite lo inefable" [2004: 75]); en la segunda cita, "dice verdad quien dice deseo" (Romero, 2017: 29) la "sombra" que equivalía a la verdad en el verso original de Paul Celan cae en favor de una idea oscura de carnalidad cognitiva, cuyo erotismo reforzará el propio cuerpo de los poemas. A lo largo de Plétora, sin embargo, se cuestionará continuamente esa realización del deseo, incluso como categoría absoluta, por medio de las grietas que se abren entre sus pulsiones de vida y de muerte... las cuales, como sucedía en el poema de Emeth, se personan a través de la evocación de su nombre: "no cabe la muerte en esta hendidura/ no puede pronunciar su nombre" (Romero, 2017: 13).

En opinión de Luis Luna, quien firma el epílogo del libro, es esta "dicotomía de posibilidad/imposibilidad" de deseo lo que "empuja a su autora hacia la persecución de un lenguaje seminal, que puje el origen. Hay por tanto metapoesía, sí, pero desde un lugar distinto al que se ha practicado en los años 90” (2017: 55). Quizás el ejemplo más claro de esa tendencia sea el siguiente texto, donde Arantxa Romero da cuenta de su cuidado en el proceso de escritura a través de un relato de plantación y germinación taumatúrgica del poema:

\author{
hundo los poemas en la tierra \\ los empapo de limo \\ para que sean origen \\ para que hagan raíz \\ toco el barro y pienso con las manos \\ de la humedad a lo extraño \\ surco a surco \\ esqueje-crecido-metáfora \\ labios como ramas germinan en bosque \\ son caminos enteros de semillas semánticas \\ ocultando la lengua de ceniza que
}


hace sombra a la respiración

todas las flores resuenan al dictado

la raíz corresponde a la voz y sin hablar

reconozco el canto

también es tierra mi garganta (Romero, 2017: 9)

En este nuevo mito de génesis poético, remarcado por la alusión al "barro" que también aparecía en las enseñanzas para "Emeth", la autora no solo se reconoce en la materialidad de la que parte su creación, sino que la modela de forma sinestésica ("toco el barro y pienso con las manos"). En la primera estrofa del poema de Cristian Piné se registraban, en paralelo, tres estadios sensoriales de conocimiento previos a la constatación lingüística: la observación -del insecto-, la escucha - de la tormenta- y, sobre todo, el tacto de "palpar tu mano densa". En los dos casos el contacto corporal resulta determinante, pues, para dar voz a lo vivo o dar vida a la voz. Aun así, donde realmente se percibe la coincidencia estética entre ambos textos es en su mención final, de descenso, a la tierra ("también es tierra mi garganta" / "debajo de la tierra está el silencio") como tope para un panorama afónico ("y sin hablar/ reconozco el canto" / "es muy difícil decir en voz alta") que se cierra con una sensación abisal de silencio fuera del lenguaje. En el caso de Arantxa Romero, dicho silencio se consigue con una imagen funeraria de cavidad enterrada, que anega y ensordece cualquier sonido que pudiera emitir.

Su efecto se potencia, además, por el apego formal que muestra la autora de Plétora a una tradición silenciaria, recogedora del testigo de José Ángel Valente y Ada Salas, distinguible en el espaciado de sus líneas, en su tendencia a la fragmentación o incluso en la plasmación visual de sus versos. Véase en este sentido "la lengua de ceniza que" cuya enunciación en voz alta realiza metafóricamente el contenido del verso siguiente ("hace sombra a la respiración”). Así, la partícula "que" no solo detiene y atasca el ritmo normal de lectura -y su respiración- sino que por su brevedad (sin ella los dos versos ocuparían casi el mismo tamaño) sobresale como un techo anómalo que deja en los ojos una suerte de huella -o de sombra-. Todo ello incide en el protagonismo de esta imagen ígnea, una de las tantas a las que recurre Plétora ${ }^{2}$, que anticipa la imposibilidad de unirse al "canto" final del poema, entendido, como todo el libro, en un marco ritual, de reiteración. Volvamos entonces al principio.

Mecánica del canto (2012) se llamaba el primer poemario de Cristian Piné y su interés original por la tensión entre las dos categorías aquí estudiadas aparecía ya en sus dos versos iniciales: "acércate y busca la síntesis de mi adjetivo,/ mi verdad latiendo en su plenitud de átomo" (2012: 13). La palabra se presentaba entonces como una reliquia que se degradaba en boca de sus portadores y a la vez era víctima de su degradación ("amigo, perdiste las consonantes entre los labios púrpuras del mito" [Piné, 2012: 25]); mientras que la verdad parecía una fuerza recóndita que el lenguaje - degradado- del poeta no podía domeñar o transmitir en su totalidad, lo que provocaba, en un juego de espejos y retazos, la desconfianza expresa hacia su labor. Sin pretenderlo manifestaba así Piné (aunque luego se alejaría de estos cauces) rasgos de la última teoría de Vicente Luis Mora en torno al concepto de "notredad", que intenta dar cuenta de tanta

\footnotetext{
2 Otra afinidad estética con Cristian Piné, mantenida a lo largo de sus tres poemarios. Sin ir más lejos, el poema que sirve de entrada al último, Asilo, concluye con la sentencia: "respetaré el silencio de las moscas/ nada será casa sin la sombra/ nada existe en esta casa si no quema” (Piné, 2017: 16).
} 
abundancia de poemas que "se cuestionan no los motivos para escribir versos (algo que, según Carlos Piera, sería de suyo la característica definitoria de la poesía moderna), sino la legitimidad del yo poético para hacerlo" (2016: 300).

La composición, no obstante, donde mejor se ilustra el conflicto entre palabra y verdad resulta no solo la más hermética del libro, sino la que quizás ha tenido más peso en la trayectoria posterior del autor. Se titula "Premutación de la verdad" y tras una increpación al lector, en medio de un lenguaje en ruinas, intenta llegar a una definición satisfactoria de la categoría:

ten tratos el ruido te asista lento
centro o trenzo color les han tormenta
trae claridad los cálido del tren
siempre rocas verdad clarividente
trastos de trozos tristes de latidos
que intentan liberar temperamentos
prefieren adaptarse a tus reductos
raptar esa tensión de los reptiles
al final te diré que la verdad
es un temor que asola nuestras vértebras
un taladro que trunca el verde centro
la alegre libertad en la catástrofe (Piné, 2012: 48).

La verdad pasa, como las estrofas, por tres etapas de revelación que se corresponden con tres modos de lenguaje, sometidos al ritmo del endecasílabo como única constante. La primera estrofa nos aboca, así, a un paisaje de ruido -concepto favorecido por su posición central en el verso de presentación- donde los significantes se cargan de significación hasta hacerse intercambiables ("centro o trenzo"), las reglas gramaticales se difuminan ("los cálido") y las aliteraciones de vibrantes, dentales y líquidas marcan los tiempos de un furioso revoltijo, reforzado por imágenes plásticas (la tormenta, el tren que acelera el ritmo) que recuerdan a cuadros de Turner como "Lluvia, vapor y velocidad". En este punto, Cristian Piné asocia la verdad a su metáfora más primitiva, la luz, pero tras superar los cortantes escollos ("siempre rocas") hasta ella, distanciará su condición natural, que de clara pasa a ser "clarividente" y, por tanto, antes adivinatoria que cierta.

En la siguiente etapa la resignación que implican los verbos ("raptar", "prefieren adaptarse", "intentan liberar" -no lo consiguen-) revela el estado de la búsqueda de la verdad, cuya huella fantasmal sigue ahora el autor a través de lo fragmentado ("trastos de trozos tristes"), de lo subterráneo ("reptiles", "reductos", "temperamentos"), en series graduales de tres, como las partes del poema, que anticipan ya el prurito geométrico de Al envés de la voz. La lógica gramatical se ha adquirido o recuperado en el proceso, pero aún queda un sonsonete fónico y una tendencia nominal a los plurales, como un sonido de multitud, que distraen de la observación de la verdad, hasta el punto de que el término "verdad" no aparece en la estrofa.

Por último, la voz poética afronta, frustrada, su definición como una concesión creativa con el lector. Para ello se basa en las impresiones que el acercamiento a la verdad ha dejado en su ánimo, en un registro que entronca con el expresionismo de Poeta en Nueva York, de García Lorca. Identifica de este modo la categoría ("taladro que trunca el verde centro") con una violencia 
fuertemente aliterada contra el hueco natural y desprotegido -lo que conecta, hasta en el valor de lo cromático, con la primera estrofa-; o con un terror mortuorio que vacía y sacude una parte de nuestro interior ("los primeros que salen comprenden con sus huesos", que dijera Lorca [1976: 51]), en consonancia con las claves de la segunda estrofa. Ambas son muestras válidas o, por mejor decir, permutaciones de las innumerables metáforas que el poeta podría haber perpetrado. $\mathrm{Y}$ es que el concepto de permutación, entendido por el DRAE como "cada una de las ordenaciones posibles de un conjunto infinito", sirve como código de interpretación de estas estrofas que remiten, para empezar, a una persona verbal diferente (segunda - "ten"-, tercera -“intentan”-, primera -“diré”-). Nótese además que los versos iniciales del poema, no sujetos a normas lingüísticas, podrían adherirse a cualquier otra combinación, como prueba la disyunción "centro o trenzo"; y que hasta el título se ofrece como ejemplo encarnado de $p-e-r-m-u-t-a-c-i-o-n$ si concedemos que el autor ha variado la posición de la $-r$ en la palabra, aplicando su propio significado a su serie de letras. Así las cosas, esa extraña premutación no sería solo un estado previo a la metamorfosis de la verdad, ni se resolvería en esa última opción, tan redonda, que hace de colofón del poema: "[la verdad es] la alegre libertad en la catástrofe". Incluso, ¿no podría remitir este verso al mismo acto de escribir como única verdad realizable?

Fue Nietzsche quien popularizó la fórmula "bailar entre cadenas" para "hablar del lenguaje, es decir, para expresar su teoría del saber” (en Longás Miguel, 2010: 84) o incluso para explicar la poesía clásica. Menos conocido es que el filósofo alemán se valió después de la metáfora para describirnos como seres inherentemente morales en Más allá del bien y del mal: "A veces, es verdad, bailamos en nuestras cadenas" (Nietzsche, 2003: 120) ¿Qué ocurriría si nos liberásemos de ellas? Hay reminiscencias de Nietzsche en "la alegre libertad en la catástrofe" de Cristian Piné, como también las hay del sentido purgativo del carnaval bajtiniano (que trae la verdad con su subversión de la norma). Reminiscencias que parecen anticipar, dos años antes de que el autor publicara Al envés de la voz, esa "danza del destino" o "baile estrafalario", donde las ideas se muestran torpes y se desploman, que expondrá en su poema sobre Emeth, y que constatan la coherencia de motivos por parte de Cristian Piné al abordar el tema de "la verdad". Entre ambos poemarios queda sin embargo un eslabón que arroja no poca luz sobre la memoria estética y la consolidación de imágenes que reproducen ciertos grupos (de islas) renovadores del panorama poético actual. Con ese eslabón me refiero a un poema, titulado "Quién miente", que Gema Palacios [1992] publica en el año 2014 como respuesta a "Premutación de la verdad".

El libro en el que está incluido, Compañeros del crimen, es un recorrido sensorial por un deseo exculpado, que destaca por su indagación léxica (todas las palabras aumentan su intensidad) y por sus estructuras de versos voladizos y fragmentos. La escritura del poemario parte de la recreación del cuerpo y la literatura. De ahí que adopte una condición "letraherida" -título de uno de sus poemas-, con resuellos neorrománticos y pizarnikianos (la autora se dirige a un omnipresente “tú”), atravesada de referencias artísticas. La asimilación de estas referencias resulta, sin embargo, más profunda de la habitual. Por ello, la cita explícita de la última estrofa de "Premutación de verdad" que abre "Quién miente" no sirve solo como marco temático-formal para el texto posterior de Gema Palacios, sino como pista o muestra de una parte del palimpsesto que está reelaborando. Dice la primera mitad del poema: 
late una espina entre párpados insomnes

sentimos el taladro de la vida con tal fuerza que nos duelen los otros ciertas noches

y a quién mentir con estos ojos trueno estallido de luces danzando aunque la rabia (Palacios, 2014: 49).

$\mathrm{Si}$ "Quién miente" arranca con la escena surrealista de un latido que perfora al desvelado ("trastos de trozos tristes de latidos", se leía en Cristian Piné) y a continuación taladra al cuerpo propio y colectivo ("taladro que trunca el verde centro"), es en la tercera estrofa cuando se invierte el sentido original del poema de Piné y de dudar por la verdad se pasa a dudar por la mentira. Los "párpados insomnes" del principio liberan entonces unos "ojos trueno" (que enlazan con el ruido y la tormenta de "Premutación de la verdad") a través de los cuales aparece ya esa danza iluminada y temblorosa que se contrapone a una situación hostil, en comunión con "la alegre libertad en la catástrofe", pero con un pie fortuito en la danza de "Emeth".

El poema se completa con otras tres secuencias, hasta culminar abruptamente con una declaración antirretórica que aviva dos frentes del conflicto de este artículo: "yo apuesto doble o nada a la palabra". Por un lado, reclama así Gema Palacios la capacidad comunicativa del lenguaje para generar nuevas realidades (verdaderas aunque tengan muros ficcionales); y, por otro lado, liga la identidad -“yo apuesto"- con el uso de este lenguaje (poético). Si incorporamos a un integrante más en este diálogo entre Piné y Palacios, ambas percepciones podrían ilustrarse con sendos extractos del poemario La edad de merecer (2015) de Berta García Faet [1988]. El primer extracto se correspondería con el rótulo-advertencia de un apartado, "Nunca fui muy enamoradiza, pero todo es verdad" (2015: 63); mientras que el segundo cierra una corriente de conciencia en torno a lo subjetivo, donde el "yo" como verdad inherente (cartesiana) se revuelve contra su condición de constructo o simulacro. Sin pretenderlo García Faet glosa, de este modo, la pregunta retórica de Palacios "a quién mentir", en una resolución que va más allá del encuentro con la palabra exacta (“yo"):

[...] ¿cómo no hablar de desamor y cómo hablar, desde el yo ajeno, y cómo no hablar? pregunto, abierta, a la puerta abierta;

conjugar es mentir, y yo me creo (García Faet, 2015: 58).

La frescura del retrato de Berta García Faet recuerda al remate, casi firma de autor, de "Fonemoramas" por parte del escritor postista Carlos Edmundo de Ory (otro de los autores revisitados en Compañeros del crimen): "si miento invento una verdad/ si me hundo me Carlos Edmundo" (Ory, 1970: 192).

No hay ningún poemario reciente, no obstante, donde se noten más las trazas de la "locura controlada" del postismo y sus intentos de reforma del lenguaje que en Asilo (2017), el último libro de Cristian Piné. En las páginas de Asilo el juego fonemorámico (de relación de sonidos), la eurritmia y la lógica permutacional que ya avanzaba Mecánica del canto coordinan en la práctica la sintaxis rota de unos versos donde el motivo de la verdad ha cedido su espacio al motivo de la enfermedad, cuyo arraigo en la poesía actual merecería un estudio monográfico... Aun así 
quedan textos que la evocan, ahora entendida como parte de un recuerdo difuso (o de las cenizas) de unos tiempos anteriores al aislamiento comunicativo, al asilo:

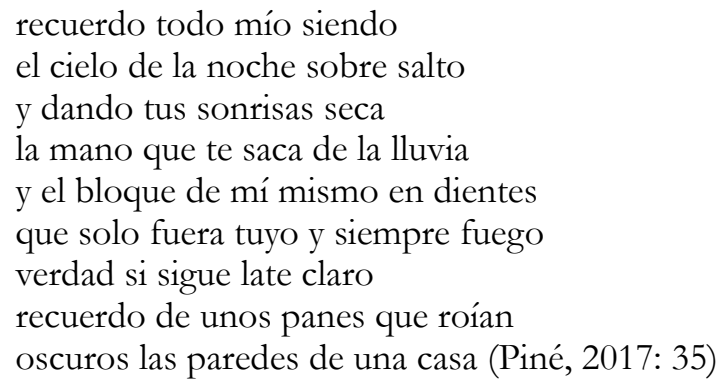

La verdad sigue vinculada a la claridad y al latido, pero en este caso a un latido también intertextual, el del poema "En un café" de Carlos Edmundo de Ory ("mi alma late late/ de sed de no sé qué"), cuyo último verso, "el cerebro está oscuro cuando arde" (Ory, 1970: 133) reverbera en los últimos versos de la composición de Piné. La luminosa "tristeza medular" de la que hablaba Ory en ese texto cobra en Asilo, sin embargo, connotaciones muy sombrías y profundas, pues si el yo poético quiere recuperar la distancia, la verdad, la normalidad del habla tiene que salir de sus puertas ("no olvides que pronto saldré del asilo/ para ser hormiga sedienta de sílabas" [Piné, 2017: 75]).

El crítico y editor Munir Hachemi advertía, de hecho, que Asilo había llegado a ese estado preconizado por Foucault donde la palabra no tiene otra cosa que decir que no sea ella misma, nada más que hacer "que centellear en el fulgor de su ser" (Foucault, 1968: 294). Animado por ello, realizó una sugerente lectura del libro basada en Foucault (1986) de Gilles Deleuze, según la cual Piné había logrado "reunir el ser del lenguaje con el del trabajo [...] y en cierto sentido también lo ha reunido con el ser de la vida" (Hachemi, 2017), las tres fuerzas del afuera (o seres) que identificaban ambos filósofos. Y es que -entiende Hachemi- la exploración lingüística en Asilo toca límites tales que recuerda a una inteligencia artificial (ser del trabajo) o incluso a un nuevo código neuronal (ser de la vida) que re-construye la relación de las palabras.

Realmente, sin salir del ámbito foucaultiano, la subversión de estas tres fuerzas podría abordarse también desde la simbología misma del "asilo" que el teórico francés estudió en su Historia de la locura en la época clásica. El asilo, no en vano, como dispositivo social niega a sus reclusos el trabajo o su valor de producción, es refugio y cárcel y sanatorio para una mente que distorsiona la vida verdadera -la oficial- en sus estancias. El paciente retuerce su comunicación en un viaje hacia dentro (de sus males) donde la lengua se presta a su delirio. ${ }^{3}$ Dice la prologuista del libro, la poeta Ángela Segovia, que "el cuerpo que aquí se percibe [...] es un cuerpo envenenado

3 Afirmación que podría glosarse con el siguiente fragmento del poemario Tuscumbia (2016) de Lola Nieto:

[...] Hablar otra sintaxis, una sintaxis enferma. Enfermo viene del latín infirmus: no firme. El enfermo es el no-firme, el que no firma, el que no afirma, el que no mira al firmamento. No mirar arriba sino abajo. No la boca sino los pies. No los ojos sino el ano. El enfermo tambalea la vida, nuestro orden, vomita, excrementa, tiene heridas. Pone en duda. Su cuerpo nos pone en duda, su cuerpo es una grieta en el muro firme de la especie. No se le compadece, no; se le odia. Porque habla otra lengua, porque su cuerpo desaprende el sentido y nos arroja a la cara una sintaxis sinsentido (2016: 18). 
de lenguaje" (2017: 9). La palabra se ha hecho enfermedad..., pero también gen último del individuo. Al final en esta trilogía de la verdad por parte de Cristian Piné (de Nietzsche a Heidegger y hasta Deleuze), al final de Asilo, lo único que sobrevive, como restos arqueológicos de un templo, son las columnas del lenguaje:

[...] porque después del después después de todo solo queda el aguijón de dios o de algo solo queda de mi cuerpo la sintaxis (Piné, 2017: 89).

\title{
DECIR LOS LÍMITES (DEL NUDO)
}

El 31 de octubre de 2017 se produjo el gesto institucional más rotundo hasta la fecha en favor de la poesía última más renovadora: la concesión del Premio Nacional de Poesía Joven “Miguel Hernández", convocado por el Ministerio de Educación, Cultura y Deporte, a Ángela Segovia [1987] por su libro La curva se volvió barricada (2016). La noticia resultaba especialmente revulsiva o esperanzadora teniendo en cuenta que hasta la publicación de La curva el interés crítico por la autora (de sólida trayectoria) se situaba aún en "la periferia de ese mapa cambiante que compone la nueva literatura: no existe otro lugar donde se pueda transitar mejor los límites del género, cultivar sentidos en las fracturas de su sintaxis" (López Fernández y Molina Gil, 2016).

En el plano gramatical La curva se volvió barricada continúa el camino de dislocación y reestructuración del lenguaje (acompañado por no pocos reclamos derridianos de una oralidad imperfecta) que emprendía su anterior trabajo, de paso a la ya tan (2013). Pero además Ángela Segovia afianza aquí los puentes que su escritura tiende (hasta en su paleta léxica) con las nuevas poéticas latinoamericanas, y experimenta con el formato textual de modo tal que el libro, editado por La Uña Rota, se convierte en un libro-objeto vanguardista traspasado por múltiples senderos, subtextos, posibilidades (o permutaciones) de lecturas en la estela de los poemas más expeditivos de José Miguel Ullán o Ulises Carrión.

No parece nada superficial, pues, que en el primer texto de La curva se volvió barricada, "mi cuerpo está cargado de/ veneno", aparezca un mantra que se repetirá en otras partes del volumen: "la verdad no hará dominio". El poema describe el encuentro epifánico con una vOz adolescente que semeja una fractura o misterio telúrico ("como la cueva que vi en una playa de Galicia y/ que tenía piel de lapas y pequeñas pezuñas de/ mar era espectacular/ la voz, me refiero" [Segovia, 2016: 9]), que le remueve. En ese punto el yo poético se habla/escribe para sí misma -haciendo confluir la oposición básica (habla/escritura) de la metafísica de Derrida- para inmediatamente modificar lo expresado y crear un nuevo lema. Un lema que resume el ideario del libro entero y que el lector asimila como voyeur de un proceso íntimo de pensamiento/redacción:

no tienes que ser sincera muchacha

me digo

y cambio un poco la frase:

\author{
"para las niñas de la vida \\ la verdad no hará dominio"
}




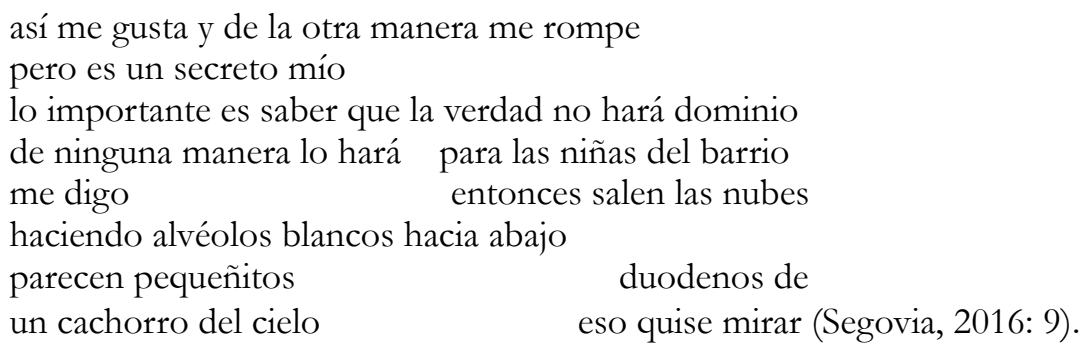

La escritura de Ángela Segovia no se orienta, por lo tanto, a la "verdad", aquí entendida como la frase o la lengua habitual, gastada, agotada en su significación (no poética). Verdadera solo por su repetición colectiva, a consecuencia de lo cual -para reparar esta falta- se precisan nuevas correspondencias. De ahí que tras concebir una forma alternativa, agitadora, de exculparse de su falta de sinceridad ("para las niñas de la vida/ la verdad no hará dominio"), acudan a la llamada metáforas intestinas insólitas (las nubes que hacen alvéolos blancos), tamizadas por un registro que bordea lo infantil ("pequeñitos", "cachorro") por sus connotaciones frágiles, etéreas o efímeras, que conectan "tanto con el trauma como con los restos de lo idealizado" (López Fernández y Molina Gil, 2016).

"Lo explícito, lo vertical/ me atraviesa la infancia" se lee en un poema, elocuentemente titulado "Semiología", de Bibiana Collado [1985], poeta que combina su conciencia lingüística e identidad de género con un estilo claro, atizado de imágenes sorpresivas ("La Habana es una sístole perpetua" [Collado, 2013: 15]). En "Semiología" asimila, como partes de una misma política de vitrinas, el catálogo de acepciones -sin aplicación viva- de un diccionario con el catálogo de relaciones -cosificadas- que se desarrollan en una pantalla, fruto de un repetido acercamiento lingüístico-sexual cuyos usos también manifiestan un deterioro de significación. El estudio oficial, cientificista y distante, de las palabras cobra así su réplica en la conducta fatal del yo poético, que trata con idénticos parámetros a los signos no verbales más primitivos (los cuerpos), a los que "encierra" tras su cristal:

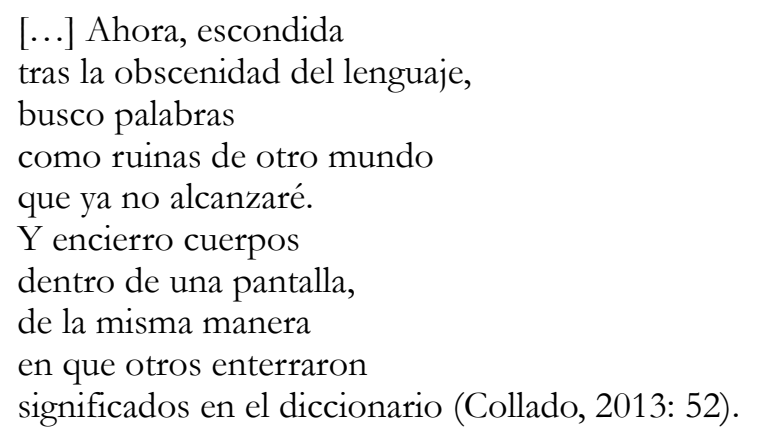

No aludo en este punto al poema de Bibiana Collado solo por su noción de un lenguaje extrañado, sino también porque la próxima vez que distingamos "la verdad no hará dominio" en La curva se volvió barricada será casualmente en el poema "una pantalla". En esta ocasión Ángela Segovia orilla las herramientas tecnológicas que ordenan y predisponen el idioma como un inventario gigante de combinaciones y sentidos ya envasados. De ahí que predique metatextualmente su incapacidad para "transar" o superar la expresión de las emociones que atraviesan sus plataformas. La pantalla, con toda su simbología de espejo posmoderno asociado a 
ella, acusa, pues, la misma "pérdida lingüística" que su referente. Sin embargo, es también su función de simulacro lo que permite a la autora proyectar una mínima subversión de términos en esa pantalla que, en una lógica de continuidad entre ventanas, dará paso a una imagen nocturna fundacional, libre para nuevas asociaciones:

[...] en esta pestañita hemos almacenado toda la información concerniente a una palabra como desolación/cariño/desnudez. Pero siempre falta algo. El ángulo negro crece crece crece

algunas tiranías aparecen sin seña en el etiquetado de la máquina, asociacionismo errático a la palabra miedo pena costumbre persecución. La pantalla se queda en blanco. Sale una herrada. Sale una clave. Sale una cifra que late en el vientre verde de una muesca

\section{LA NOCHE NOS REGALA SUS PALABRAS EN ELLAS LA VERDAD NO HARÁ DOMINIO (Segovia, 2016: 39)}

Las mayúsculas son importantes. Casi semejan el grito de una concentración popular. Y es que desde el título del poemario, La curva se volvió barricada, se aprecia una noción de resistencia, que se materializa en el interés (revolucionario) por la torcedura de las líneas del idioma, de los recursos literarios más saturados. Forzar una curva. Deleuze, citando a Proust, apuntaba que un gran escritor es quien "inventa dentro de la lengua una lengua nueva, una lengua extranjera en cierta medida [...], saca a la lengua de los caminos trillados" (1997: 9). En bastantes poemas de Ángela Segovia se percibe una voluntad simultánea de movimiento y de escaparate, como si sus libros encarnaran, en la poesía española, un prodigioso carro ambulante que intenta mostrar y abrir a su paso nuevos caminos comunicativos..., pero por la vía más intrincada y rupturista. En una vuelta de tuerca de los posicionamientos clásicos en torno a debates (reduccionistas, pero ilustrativos) como la poesía en tanto conocimiento o comunicación, La curva se volvió barricada se inclina desde sus paratextos al segundo propósito; busca regular nuevos acercamientos con el lector, más allá de la reacción ante la extrañeza del texto: "La poesía", reclama Ángela Segovia en la contraportada, "sirve para hacer un lenguaje que complica, abre, entorpece y amplía la comunicación". ${ }^{4}$ En este caso, a través de una lectura de vanguardia donde el trabajo radical con la forma poética -fracturada, interrumpida, llena de remedos de hablas callejeras, metáforas turbadoras, etc.- implica ya su mensaje. Un mensaje que no se ciñe ni se dirige, en consecuencia, a ninguna verdad externa. Bien podrían servir de apostilla para los dos últimos versos del poema "una pantalla", en este sentido, aquellos con los que Antonio Méndez Rubio advertía la consciencia sonámbula de un lenguaje que confina en su universo -espectral- de referencias todo lo nombrado: "Toda la noche y/ toda la verdad... son/ palabras/ a la búsqueda de cualquier cosa/ menos de sí mismas" (Méndez Rubio, 2013: 80).

\footnotetext{
4 Como crítica y lectora Ángela Segovia ha acusado también esa esperanza al reseñar poemarios recientes caracterizados por un estilo oscuro o exigente, como Asilo de Cristian Piné, más cercano al empleo del lenguaje poético como ejercicio de conocimiento y experimentación interna. Aun así, al concluir su estudio introductorio apostillaba Segovia, prologuista del libro: "Yo creo que en parte hay una confianza en la posibilidad comunicativa del lenguaje poético, con toda su herrumbre, su tensión, su enfermedad, una confianza en ese tocar y hacer contacto, que es, al cabo, una posibilidad de amor, y la posibilidad de un nosotros. La posibilidad de sernos aquí: «Somos sitio Somos este sitio somos / este este este sitio este de aquí»” (Segovia, 2017: 10).
} 
Quizás las propuestas de renovación poética más parejas a la de Ángela Segovia en cuanto a su resolución en papel sean hoy, en cualquier caso, la de la escritora y artista sonora María Salgado [1984] (quien forma parte del dispositivo de lectura, escritura y pensamiento colectivo Euraca. Seminario de investigación en lenguas y lenguajes de los últimos días del euro, en el que Ángela Segovia participa activamente) y, sobre todo, la de la ya citada Lola Nieto [1985] (coordinadora, a su vez, de la revista Kokoro y de la colección "Kokoro Libros" de la editorial Kriller71). En libros como alambres (2014) o Tuscumbia (2016) Nieto ha compuesto unos poemas movedizos, de lenguaje muy convulsionado y frágil en sus ligaduras, donde el blanco del folio actúa casi como tarima. Secundada por múltiples ritmos (desde la nana a una prosa poética desatada de puntuación), los personajes en este espacio se muñequizan o asalvajan movidos por una lógica mistérica que acompasa todo. Es una lástima para este artículo que apenas hayan desarrollado, al menos explícitamente, el conflicto entre verdad y lenguaje. Sin embargo, conviene adjuntar un extracto de una entrevista no muy lejana donde la autora establecía libremente la conexión entre las dos categorías. La pregunta era: “¿Crees que hay más valor en una voz madura o en una vOZ más emocional?”. Su respuesta no puede no vehicularse con la poética de Ángela Segovia (en todo caso, desde una perspectiva más lúdica hacia el texto):

Creo que una cosa y otra no son contradictorias ni excluyentes. Una voz madura puede ser emocional o no. Y una voz emocional puede ser madura o no. Personalmente, cuando leo, me interesa encontrar cierto trabajo con el lenguaje, que las palabras se pongan en duda, se cuestionen, vibren, se hagan y deshagan constantemente. Que no digan la verdad sino que la rompan contra el suelo para dibujar muchas formas que en cuanto estén dibujadas se borren otra vez (Nieto, 2015).

Como un niño cuando habla. La poesía de ambas autoras llega, no obstante, a funcionar como un refinado balbuceo que sortea por lo primitivo o por lo abstracto las fronteras del lenguaje. Y es que en su propuesta los límites del lenguaje exceden a los del mundo. El objetivo, entonces, no es tanto deshacer los nudos comunicativos de la lengua, como reivindicaba Wittgenstein, sino hacer otra cosa -poética- con ellos. No hallar la palabra redentora (Das erlösende Wort) que exprese de forma absoluta, sino las palabras permeables que consigan expresar lo otro por otros caminos.

Como sea, en la actualidad abruma la cantidad de respuestas literarias que se están produciendo a raíz de la combinación tripartita de verdad, lenguaje y una noción de agotamiento de significados. No solo en poesía. El caso más destacado es quizás el del dramaturgo Juan Mayorga, mayor en años que los poetas estudiados pero auténtico protagonista y catalizador, junto con Angélica Liddell, de la renovación teatral española del siglo XXI. ${ }^{5}$ En una edición reciente, el profesor Peral Vega (2015) ratificó que la tragedia mayorguiana tiene raíces verbales, fruto de la pérdida de significación de un lenguaje que se ha ido desgastando o pervirtiendo como medio de comunicación. En consecuencia el escritor nos expone, dialécticamente, la (im)posibilidad de reencontrarnos con ese diálogo que hemos perdido. Y es que el diálogo para Mayorga, en consonancia con el pensamiento de Walter Benjamin, supone el mejor modo de

\footnotetext{
5 Conviene mencionar además - para reforzar el vínculo- que la mayoría de piezas de ambos dramaturgos se han publicado en La Uña Rota, la editorial a la que Ángela Segovia confió La curva se volvió barricada y donde ha traducido recientemente el poemario CO CO CO U (2017) de la poeta gallega Luz Pichel.
} 
desvelar la verdad. Se materializa así una poética teatral -y ética- del conocimiento a través de la restitución de los cauces comunicativos. Es otra postura del conflicto, que entronca con el segundo Wittgenstein en tanto entiende que la verdad está en el lenguaje. Creer en esta fórmula, sin embargo, implica asumir su reverso, que la verdad no existe hasta que la decimos, y, como escribía Cristian Piné en su poema sobre Emeth, "es tan difícil decir en voz alta”...

Relacionado con esta necesidad de decir o de decirse, el poeta y crítico Alberto Santamaría interpretó el libro ya citado La edad de merecer, de Berta García Faet, desde una óptica de fracaso de la palabra (pues "fracasa más y mejor.// la palabra/ palabra/ fracasa más y mejor" [García Faet, 2015: 26]), que trata de representar o incluso pegar los pedazos de un yo huidizo y, por tanto, en "constante estado de esquizofrenia" lingüística, a lo largo del pasado, el presente y el futuro (Santamaría, 2017: 71). Para hallar las pistas de este fracaso metapoético, y sobre todo su conexión con el tiempo, el crítico alude a la sección "Trece tesis para la mejor comprensión de los pájaros en edad de merecer", donde Berta García Faet partía, de hecho, de "un desvío del texto wittgensteniano del Tractatus"6 (Santamaría, 2017: 71).

Existe otro poema en La edad de merecer, no obstante, que no solo explicita la relación entre verdad y lenguaje (con referencia a Wittgenstein de por medio) sino que varía sus estadios de tensión al incorporar otra categoría al conflicto: la memoria. El texto, titulado "poema del río leteo", se configura como una corriente de conciencia donde -como es característico en la autora- se cruzan retóricas de identidad, deseo y corporalidad, aunque para reflejar el estado de pérdida que causan sus aguas (beber de ellas provocaba un olvido completo) los tramos temáticos aparezcan calculadamente más concentrados de lo habitual. Así las cosas, la voz comienza su incursión recordando, en tono naíf, su noción enciclopédica sobre ese espacio mítico, a partir del cual despliega todo un muestrario de estrategias de significación: desde la descripción a la definición, desde la adscripción a la apropiación e interiorización del sentido o, incluso, la etimología. Todo en un tiempo presente de inalterable continuidad:

el río leteo es uno de los ríos del hades. las branquias tostadas del atardecer son siempre las mismas. el color del molusco llamado múrice (el color del sobresalto) forra el cielo y el agua. la forma del molusco llamado múrice (la forma de la peonza con espinas) imita la forma de mi corazón. leteo significa olvido y a significa sin. río significa río. letheia significa sin olvido y aletheia significa verdad... (García Faet, 2015: 53)

Es en el extracto final del texto cuando estas estrategias de significación, que no habían escatimado marcadores de certeza ("siempre”), se trasmutarán primero en recuerdos de reconocimiento sensorial ("una vez palpé una nuca policontusionada y era tu nuca") y justo después en recuerdos de mecanismos de especulación y proyección ("imaginé comprender qué es la belleza"), de lo concreto a lo abstracto, descritos en un pasado verbal que violenta por lo abrupto de su asunción. Toda esta lógica de flashback lleva a la voz poética a (de)construir el origen mismo de la Verdad como entidad mítica, primer paso para ponerla en duda junto a su realización asociada a la memoria. Gracias a ello Berta García Faet añadirá una nueva permutación a nuestra lista de la verdad (“es un terrón de moho"), en medio del remolino de

\footnotetext{
${ }^{6}$ Una muestra de la recurrente presencia de Wittgenstein en la poesía española última, también como mito, es el texto "Ludwig" (2012: 57), de Alejandro Simón Partal [1983], donde la redacción del Tractatus y su noción de los límites de lenguaje llegan a replantearse en clave de propuesta erótica.
} 
motivos ya abiertos y la reiteración de términos que se rizan ("si fuera verdad que la verdad es un recuerdo”) en el que acaba desembocando su recreación posmoderna del olvido del río Leteo. Un proceso de olvido cuya pérdida de asideros veraces e inteligibles permite (meta)poéticamente encarnar, o al menos rozar, los referidos "límites del lenguaje" justo cuando se traspasan los límites de la vida -el Hades-:

[...] una vez palpé una nuca policontusionada y era tu nuca. imaginé o comprendí que tu piel es transparente. imaginé comprender qué es la belleza. la Verdad con mayúscula fue una diosa encantadora, hija del Tiempo y de la Virtud con mayúsculas. antes, la estética y la bondad iban a todas partes juntas. mi fantasía sexual de acorralar al oprimido hubiera resultado muy erótica y moral. di, por ejemplo, amor. (alguien pronuncia: write down your email and $i^{\prime} l l$ check if you exist.) di, por ejemplo, amor. (¿ves? choca contra la llaga, vuela y rompe la bombilla.) el mito y el azúcar se disuelven. si fuera verdad que la verdad es un recuerdo, yo me rebelaría contra la verdad. la verdad es un terrón de moho. el recuerdo es imposible. no todo se olvida porque no todo pasa. las cosas del mundo imitan la forma de mi corazón y tiene el color del sobresalto. di, por ejemplo, amor. y ya no está. nunca estuvo. no es magia, no es traspié. son los límites del lenguaje. y del río. tú, mueca neobarroca. hacia arriba. y desciendes (García Faet, 2015: 54)

Por encima de su descendimiento, la resolución de ese horizonte de pérdida (tan escheriano en la parte final) se encuentra en el desdoblamiento de la voz poética, que termina por no reconocerse en su reflejo o no reconocer a su desfigurado interlocutor ("tú. mueca neobarroca"). Antes de ello, la voz ya había intentado hasta tres simbólicas veces materializar, con dosis de ironía, el contenido y la correspondencia de la palabra amor, instando(se) a pronunciarla en vOz alta ("di, por ejemplo") en un ejercicio de acompañamiento. Por fortuna, quien pierde la memoria a ojos del que se hunde siempre es el otro: "desciendes"... Sin salir de este imaginario acuático, Chantal Maillard propuso una interiorización lingüística similar en su composición "El pez", donde las palabras, colean, brotan y sobre todo lanzan, como García Faet, instrucciones al lector en un juego de seguimiento textual que rompe la cuarta pared y la aboca al abismo: "Repite, entonces, conmigo Infinito./ Di infinito. Repítelo. No dejes/ de decirlo, hasta que pierda/ sentido la palabra infinito y/ te encuentres en el vértigo,/ desprovisto de pértiga" (Maillard, 2007: 56).

En cualquier caso, no deja de ser significativo que la última indicación que se dé el "yo" poético a sí mismo o que intente comunicar más allá de la muerte sea el decir un amor que de inmediato cobra connotaciones quevedescas, aunque queden insatisfechas después "de dejar la memoria, en donde ardía" (Quevedo, 1982: 80) al cruzar el Leteo. ¿Qué queda entonces del lenguaje en sus orillas?

La pregunta podría contestarse con un poema inserto en Ruidos (2014), de Lucía Boscá [1985]. En este libro, cargado de una conceptualidad barroca, aunque no lo parezca por su desnudez y tradición silenciarias, la escritora ejecutaba una poética de la crisis y de la tachadura derridiana (No vas a venir, ¿verdad? / En un sele grite" [Boscá, 2014: 44]) como muestra de nolugares visibles de enunciación. En consecuencia, el conocimiento pleno del lenguaje (único territorio de representación) solo se lograba a través del contacto con los que no-están pero se ven, corren, respiran o dejan de hacerlo entre unas ruinas recientes: "abrir o continuar/ traspasándolo. Entre/ los muertos/ conociste el lenguaje:/ ésa era tu alabanza. [...] Estuviste 
muerto y hubo/ No lo volviste a intentar./ No era ni ningún rezo./ Y esa fue tu alabanza.” (2014: 30). El último ruido de la verdad.

\section{LiTURGIA DE LA PALABRA. CODA}

Como destapan las resonancias salmódicas del poema de Lucía Boscá, hay otro modo de búsqueda e interpretación del lenguaje capaz de remontar los umbrales del conocimiento y que cierra, en la práctica, el círculo abierto con el poema sobre "Emeth": la escritura sagrada, la palabra de Dios, a cuya sombra alargada se ha asomado también la poesía última, con una voluntad de erosión, cargada de resortes vanguardistas.

El eterno enfant terrible de las letras españolas, Leopoldo María Panero, apuntalaba así la metáfora que daba título a su volumen de 2008 Escribir como escupir: "Escribo como escupo/ como si estuviera el cadáver de Dios/ hecho tan sólo de saliva/ Y Dios es tan sólo una mentira en la ruina" (2008: 17). No es solo que la labor de escritura -falsaria divinidad- nazca muerta y se arroje, como un despojo fisiológicamente necesario, al papel, sino que Panero despoja con él a Dios -inequívocamente vinculado con España en el poemario- de su única condición inherente, la verdad, en una fuga de desengaño barroco ("mentira en la ruina"). Y es que la verdad es el dolor, la muerte, los heraldos vallejianos vueltos hacia el interior del odio del hombre: "Porque Dios nos ilumina aplacando las iras del corsario/ del corsario negro del espíritu/ que nada sabe de Vírgenes ni de santos/ sino de la verdad/ verdad o estrella oxidada en medio de una carretera" (Panero, 2008: 12). La verdad se pisa, se hace añicos en una imagen de luz gastada con la que el lenguaje de Panero (su acercamiento poético) fuerza la cita del Tractatus de Wittgenstein que sirve de obertura al libro: "De lo que no se puede hablar, mejor es callarse" (en Panero, 2008: 6).

En 2014 aparecerá otro poemario que descarna la palabra de Dios y los imaginarios bíblicos y cuyo título, inspirado por un versículo del "Libro de los salmos", se contrapone a aquella cita wittgensteniana. Me refiero a El silencio de las bestias (2014), de Unai Velasco [1986], poeta caracterizado por una escritura visionaria torrencial, en la que integra y desarrolla como un rizoma decenas de referencias pop (y que le hizo merecedor del Premio Nacional de Poesía Joven "Miguel Hernández" 2013). En esta ocasión, Velasco exhuma la estructura y la retórica salmódica de una misa católica para reelaborar y construir sobre sus cimientos un edificio lírico que se divide entre el terror a la palabra como canto divino y la necesidad sanadora de su encuentro, lleno de cuerpos temblorosos y de estancias vacías -salvajes y sepulcrales- que se rellenan textualmente a la par que avanza su recorrido.

En ese marco, su texto "Que somos buenos" podría glosarse con aquella segunda permutación de Cristian Piné, "[la verdad] es un temor que asola nuestras vértebras", pues la voz poética niega la evidencia ("mientes") de su reflejo y de los amenazantes animales, de cuño freudiano y apocalíptico, que proyecta su inconsciente moral, teñidos de un cromatismo que recuerda tanto al expresionismo de Der Blaue Reiter como a las vidrieras medievales:

Tengo miedo de las avispas tengo miedo amarilla ictericia amarilla

hueso de pollo alojado en la garganta de las bestias alojadas en la garganta. 
Caballos blancos cinchas azules ¿qué has de temer?

de cincha amarillo y caballo ictericia temes

las patas otorgadas de los ciervos

que duermen sobre las hojas.

Detente y escucha.

Mientras cristal venido abajo.

No no tendré no tengo miedo soy bueno y observé

los ciervos blancos ciervos traducidos de sol

contra mi ventana.

Mientras cristal venido abajo vienen a tu portal

por la mañana.

No temo al temor temo al portal

temo tu anillo negro de los malhumores... (Velasco, 2014: 29)

Es el temor o, por mejor decir, la mortificación del penitente. Esta espiral de combinaciones y mise en abyme se intensifica ("tengo miedo del miedo de las avispas del miedo de los ciervos") hasta culminar en una sofocada ofrenda corporal ("en pira de bondad detente") que la voz poética cierra -he ahí la subversión- con un eco lingüístico anticipado de la sentencia misma de Dios (“y escucha sobre todo escucha y que así sea y que así/ sea”). De este modo, al tiempo que reclama su atención -su silencio-, se apropia y escenifica la condición ejecutora, el "acto de habla" que va ligado al discurso divino, enfocado a lo largo de toda la sección que contiene este poema, "Liturgia de la palabra".

La impronta que la verdad, como categoría de inspección moral y epistemológica, tendrá en dicha sección se adivina ya con la cita introductoria de Bob Dylan, "So let us not talk falsely now", perteneciente a la canción "All along the watchtower", cuyo sentido de vigilancia percute varias composiciones de Velasco. La más clara es el poema "Monasterio", donde el escritor se vale de una enajenada corriente de conciencia, con remedos de varias neurosis (misófoba, aritmética...), para proyectar la toxicidad de una pareja, sostenida en torno a dos claves: la acusación penal y la obediencia monástica. La vía judicial y la sacramental: las dos formas de legitimar una unión. Desde el principio ("Benny pronunciación no me mientas no me mientas te doy treinta y dos oportunidades treinta y dos celdas aisladas del mutante estreptococo Benny maitines que estás a mi lado a veces te hablo y no me escuchas") Unai Velasco desarrolla en ráfagas sueltas ambos ámbitos dedicados al servicio de la Verdad ("creo en ti"/ "no pronuncias bien mientes"), pero no los enlaza hasta su conclusión, cuando resignifica el icónico juramento del declarante sobre la Biblia -mostrado en tantas películas sobre juicios- asociado a una actitud dual de exigencia y confesión: "[...] y eso nos separa porque yo de ti quiero la verdad la verdad y nada más que la verdad" (Velasco, 2014: 42). Otra pista de interpretación de "Monasterio" está en la llamada "ruminatio" que antecede en cursivas al cuerpo del texto. Y es que el concepto remite a la extenuante técnica clerical de meditar y meditar un texto bíblico hasta re-conocerlo y, por asimilación, advierte del estado lingǘstico alterado de esa voz obsesionada por su deseo de $\operatorname{verdad...}$ 
En contraste, la mayoría de las veces esta comunión entre lenguaje y conocimiento en El silencio de las bestias no llega a concretarse, por más que se desacralice o se acerque al punto de enunciación, ni para salvar ni para condenar, como una promesa kafkiana. Por ejemplo, en el poema "Daniel San recibe una paliza en la playa pero no es Daniel San", que describe una callada experiencia sexual entre dos amantes primerizos, después de la pausa final que debía preceder a la respuesta verbal, solo se acierta a remitir a la imagen fabulosa con la que se abría la composición: "cerca la boca hambrienta tuya/ mirando/ como queriendo explicarme en silencio/ como a punto de decir.// Jabalís a puñados bajan del valle de San Fernando" (Velasco, 2014: 41). Se describe así un círculo eterno, casi una liturgia, de encuentro en la mudez.

De forma parecida, el poeta Álvaro Guijarro [1990] termina su alucinado catálogo de escenas que vale la pena imaginar -en su texto titulado "Intangible"- con la estampa de "un espectáculo radiante para los iluminados monjes/ pero también para aquella mujer/ y aquel hombre comunes que [...] duermen en su alquiler movible/ creyendo creer creer creer que nada tienen que decir" (2017: 24). La poesía de Álvaro Guijarro, una de las más versátiles del panorama, destaca por su exuberancia léxica al servicio de la imagen y del misterio. La nota es aplicable a su último libro, Siglo XXIII (2017), enmarcado en una suerte de distopía, que se orienta, sin embargo, hacia la nostalgia presente y hasta la revisión de lo mítico. Así las cosas en su poema "Hablemos de categorías" Guijarro reelabora desde una postura próxima al creacionismo literario una clasificación trimembre de grupos de personas que, en una inversión teológica final, se completa con la alusión a un cuarto grupo al que describe con evocaciones románticas y al que etiqueta como "Dios". Es decir, el tan ansiado hallazgo de la palabra o el nombre divinos se descubre al final, desde el siglo XXIII, como una virtud humana, desprovista de toda univocidad, que marca el límite de la categorización y aspiraciones de la especie, sin opción a réplica: "Y luego hay otra tipología extraña,/ motivo de pólvora y noche abandonada y sonriente,/ tesoro/ aún insólito/ y cuyo nombre es Dios" (Guijarro, 2017: 49). Ya Berta García Faet -que se suma a esta tendencia litúrgica en el título de su último libro, Los salmos fosforitos, una propuesta de escritura contrastiva a partir de Trilce- hizo alusión al "gnosticismo" del poemario de Guijarro en la misma contraportada de este.

Como sea, la reescritura mítica más reveladora que acomete Siglo XXIII se cristaliza en los dos últimos versos de la composición "Únicos y repetibles" cuando consigna con vocación aforística: "frágil es/ quien no se sabe" (2014: 51). La advertencia parte de la célebre inscripción del templo de Apolo en Delfos ("conócete a ti mismo"), pero con una significativa desviación: "saber" frente a "conocer". Dos verbos que, en el plano semántico, se distinguen por su grado de compromiso de certeza con lo enunciado: aquello que se sabe, frente a lo que solo se conoce, resulta inherentemente verdadero. La búsqueda de la verdad, no en vano, es el telón de fondo de este poema, que apela a la singularidad (también poética-lingüística) como medio para lograr un acto significativo, que tenga continuidad. Lograr ser repetibles, pero, en diálogo con los versos precursores de Chantal Maillard (con los que se abría este artículo), desquitándonos del ansia de repetirnos que instaura las otras verdades, las que no-son. A este respecto comenzaba así Guijarro su poema: "es difícil la especie, y avanzar/ con un signo que sea un signo trascendente/ es muy difícil". Un cántico al que podría acoplarse, casi con exactitud, el poema sobre Emeth que iniciaba este recorrido: "tan difícil escuchar cómo nace una tormenta/ y decir que está naciendo, 
es muy difícil", lo que delata un proceso de espejo o de memoria estética que aproxima aún más las islas de los autores comentados. Toquemos tierra.

\section{A MODO DE CONCLUSIÓN}

Las aproximaciones más lúcidas a la poesía española última han caracterizado a esta por su liquidez (Molina Gil, 2015) en tanto que el panorama joven parece ajeno a manifiestos, etiquetas colectivas, conciencias de bando, sentimientos de grupo y demás asociaciones que canalizaron las corrientes de las décadas previas. A pesar de ello, no solo median entre los autores de vocación más renovadora unas coordenadas estéticas y argumentos comunes, sino que se retroalimentan en los hallazgos del otro en una vertiginosa dinámica de incorporaciones y lecturas, reflejo del "espíritu del tiempo" de esta década, que va revelando un perfil poético de vanguardia cada vez más consciente de sí mismo. Más sólido.

Estas afinidades textuales se estrechan cuando se estudia un tema metaliterario como el propuesto, que remite al propio proceso de manufactura del poema. $\mathrm{Y}$ es que en la tensión (de escritura) entre verdad y lenguaje se descubre parte de su andamiaje estético y de sus motivaciones expresivas (el cansancio de significar, la identidad lingüística, la revisión mítica, las incursiones comunicativas o epistemológicas del poema, etc.). Relacionado con ello, conviene destacar el complejo aparato teórico (Derrida, Deleuze, Foucault...) que desarrollan los poemarios analizados, así como su agudo conocimiento y reinterpretación de las poéticas del siglo XX más vibrantes e insólitas, como el postismo, aún hoy a la sombra del canon. Este bagaje sumado a la experimentación formal que subyace en varios de sus textos ha podido provocar, sin embargo, un prejuicio de lectura sobre su estilo, que de exigente ha pasado a equivaler a oscuro, y de oscuro a entenderse como opaco. Ante estos derroteros, la labor benjaminiana del crítico como un alumbrador de sentidos resulta fundamental, especialmente en las poéticas menos figurativas, como las de Cristian Piné o Ángela Segovia, por citar a dos de los autores más representados en el artículo.

Dicha urgencia crítica se agrava si se tiene en cuenta que, en términos de porcentaje, este es el género literario que más ha crecido en número publicaciones a lo largo de los últimos años, así como en visibilidad institucional, comercial y cultural: hay un auge de poesía, también renovadora. Habrá que renovar entonces los mapas y los puentes de sus islas. 


\section{BIBLIOGRAFÍA}

BAgué Quílez, Luis y Santamaría, Alberto (eds.) (2013). Malos tiempos para la épica. Última poesía española (2001-2012). Madrid: Visor Libros.

BAGuÉ Quílez, Luis (2015). “Un yo 'en off': políticas del sujeto en la poesía reciente”. SÁnCHEZ, Remedios (ed.). Palabra heredada en el tiempo. Tendencias y estéticas en la poesía española contemporánea (1980-2015). Madrid: Akal: 369-381.

BARTHES, Roland (1957). Mythologies. Editions du Seuil: París.

BATLló, José (ed.) (1968). Antología de la nueva poesía española. Madrid: Ciencia Nueva (El Bardo).

BATLLÓ, José (ed.) (1974). Poetas españoles postcontemporáneos. Barcelona: El Bardo.

BosCÁ, Lucía (2014). Ruidos. San Sebastián de los Reyes, Madrid: Ayuntamiento de San Sebastián de los Reyes.

CABEZÓn, Enrique (2013). Desdecir. Colmenar Viejo, Madrid: Amargord Ediciones.

CANTOS Aparicio, Marcos (2014). El problema de la revelación de Dios desde una filosofía primera en X. Zubiri. Fundamentación, indole y maximidad. Madrid: Ediciones Universidad San Dámaso.

Castellet, José María (ed.) (1970). Nueve novísimos poetas españoles. Barcelona: Barral.

Collado, Bibiana (2013). Como si nunca antes. Valencia: Pre-Textos.

Deleuze, Gilles (1997). Crítica y clínica, traducción de Thomas Kauf. Barcelona: Anagrama.

Eloy-GarCíA, María (2007). Cuánto dura cuanto. Almería: El Gaviero Ediciones.

Floriano, Miguel y Rivero Machina, Antonio (eds.) (2016). Nacer en otro tiempo. Antología de la joven poesía española, prólogo de Álvaro Valverde. Sevilla: Renacimiento.

FOUCAULT, Michel (1968). Las palabras y las cosas: una arqueología de las ciencias humanas, traducción de Elsa Cecilia Frost. México, D.F.: Siglo XXI Editores.

GARCíA, Miguel Ángel (ed.) (2018). El canon del compromiso en la poesía española contemporánea. Antologias y poemas. Madrid: Visor Libros.

GARCíA FAET, Berta (2015). La edad de merecer. Córdoba: La Bella Varsovia.

GARCÍA LORCA, Federico (1976). Poeta en Nueva York. Barcelona: Lumen.

GuijArro, Álvaro (2017). Siglo XXIII. Sevilla: La Isla de Siltolá.

Hachemi Guerrero, Munir (2018). "Poesía posthumana”. Revista de Letras, 19-02-2018.

Heidegger, Martin (1996). Caminos de bosque, versión de Helena Cortés y Arturo Leyte. Madrid: Alianza.

IraVEDRA, Araceli (ed.) (2015). Hacia la democracia. La nueva poesía (1968-2000). Madrid: Visor Libros. 
LANZ, Juan José (1993). Introducción al estudio de la generación poética española de 1968, tesis doctoral dirigida por Sabina de la Cruz García. Madrid: Universidad Complutense de Madrid.

LANZ, Juan José (2009). Conocimiento y comunicación: textos para una polémica poética en el medio siglo (1950-1963). Palma de Mallorca: Edicions UIB.

LONGÁs Miguel, Ángel (2010). El grado de doctor: entre la ciencia y la virtud. Zaragoza: Prensas Universitarias de Zaragoza.

LÓPEZ FERNÁNDEZ, Álvaro y MOLINA GIL, Raúl. “Reseña de Segovia, Ángela (2013), De paso a la ya tan, Madrid, ÁRTEse quien pueda, 89 pp”. Cuadernos de Aleph 8 (2016)

LunA, Luis (2017). “Epílogo”. Romero, Arantxa. Plétora. Colmenar Viejo, Madrid: Amargord Ediciones: 53-57.

MAILLARD, Chantal (2004). Matar a Platón; seguido de Escribir. Barcelona: Tusquets.

MAILlard, Chantal (2007). Hilos; seguido de Cual. Barcelona: Tusquets.

Martín gijón, Mario (2014). Tratado de entrañeza. Madrid: Polibea.

MartíneZ, Yaiza (2012). Caoscopia. Colmenar Viejo, Madrid: Amargord Ediciones.

MÉndeZ RUBio, Antonio (2013). Va verdad. Madrid: Vaso Roto Ediciones.

Miguel, Luna (ed.) (2011). Tenian veinte años y estaban locos. Córdoba: La Bella Varsovia.

MogA, Eduardo. “Los habitantes del río”. Quimera: Revista de literatura 377 (2015): 66.

Molina Gil, Raúl (ed.) (2015). No sé si no en la herida. Antología de poetas líquidos. Barcelona: Megustaescribir.

MORA, Vicente Luis (2016). El sujeto boscoso: tipologías subjetivas de la poesía española contemporánea entre el espejo y la notredad (1978-2015). Madrid: Iberoamericana / Frankfurt am Main: Vervuert.

Morante, José Luis (2016). Re-generación: antología de poesía española (2000-2015). Granada: Valparaíso Ediciones.

NAvAL, María Ángeles (2010). "Historia e historia literaria en la poesía del realismo posmoderno”. Naval, María Ángeles, ed. Poesía española contemporánea. Madrid: Visor Libros: 119-143.

NiETO, Lola (2015). “Entrevistas. Lola Nieto”. Psychonauts.

NiETO, Lola (2016). Tuscumbia. Madrid: Harpo Libros.

NiETzSCHE, Friedrich (2003). Más allá del bien y del mal, traducción y notas de Andrés Sánchez Pascual. Madrid: Alianza.

Ory, Carlos Edmundo de (1970). Carlos Edmundo de Ory. Poesía 1945-1969, edición de Félix Grande. Barcelona: Edhasa.

Palacios, Gema (2014). Compañeros del crimen. Madrid: Ediciones Paralelo.

PANERO, Leopoldo María (2008). Escribir como escupir. Madrid: Calambur. 
Peral Vega, Emilio (2015). “Introducción”. Mayorga, Juan. Hamelin; La tortuga de Darwin, edición de Emilio Peral Vega. Madrid: Cátedra: 9-107.

PINÉ, Cristian (2012). Mecánica del canto, prólogo de Álvaro López Fernández. Colmenar Viejo, Madrid: Amargord Ediciones.

PINÉ, Cristian (2014). Al envés de la voz: Zúrich: LUMA Foundation

Piné, Cristian (2017). Asilo, prólogo de Ángela Segovia. Madrid: Ediciones Paralelo.

PRIETO DE PAUla, Ángel L. (2010). "Acordes del desconcierto: encrucijadas de la poesía española actual”. NAVAL, María Ángeles (ed.). Poesía española contemporánea. Madrid: Visor Libros: 17-37.

Quevedo, Francisco de (1982). Antología poética. Francisco de Quevedo, selección y prólogo de Jorge Luis Borges. Madrid: Alianza.

RAMÓN, Esther (2015). Desfrío, epílogo de Antonio Méndez Rubio. Madrid: Varasek.

Romero, Arantxa (2017). Plétora, epílogo de Luis Luna. Colmenar Viejo, Madrid: Amargord Ediciones.

SÁnCHEZ, Remedios (2015). "Presentación". Sánchez, Remedios (ed.). Palabra heredada en el tiempo. Tendencias y estéticas en la poesía española contemporánea (1980-2015). Madrid: Akal: 5-7.

SANTAMARÍA, Alberto (2017). "La imagen en el poema. Una proyección cartográfica de la poesía española reciente”. Versants. Revista suiza de literaturas románticas, 64, vol. 3 (2017): 67-79.

SEgOVIA, Ángela (2016). La curva se volvió barricada. Segovia: La Uña Rota.

Segovia, Ángela (2017). "Espejeos de a(1)s(i)lo". Piné, Cristian. Asilo. Madrid: Ediciones Paralelo: 7-10.

SIMÓN PARTAL, Alejandro (2012). Nódulo Noir. Sevilla: Renacimiento.

Velasco, Unai (2014). El silencio de las bestias. Córdoba: La Bella Varsovia.

VV.AA (2017). Voz vértebra. Antología de poesía futura. Barcelona: Kriller71.

WANG, Minke (2013). Mòh, presentación de Juan Carlos Mestre. Colmenar Viejo, Madrid: Amargord Ediciones.

ZizeK, Slavoj (2006). Visión de paralaje, traducción de Marcos Mayer. Buenos Aires [etc.]: Fondo de Cultura Económica. 